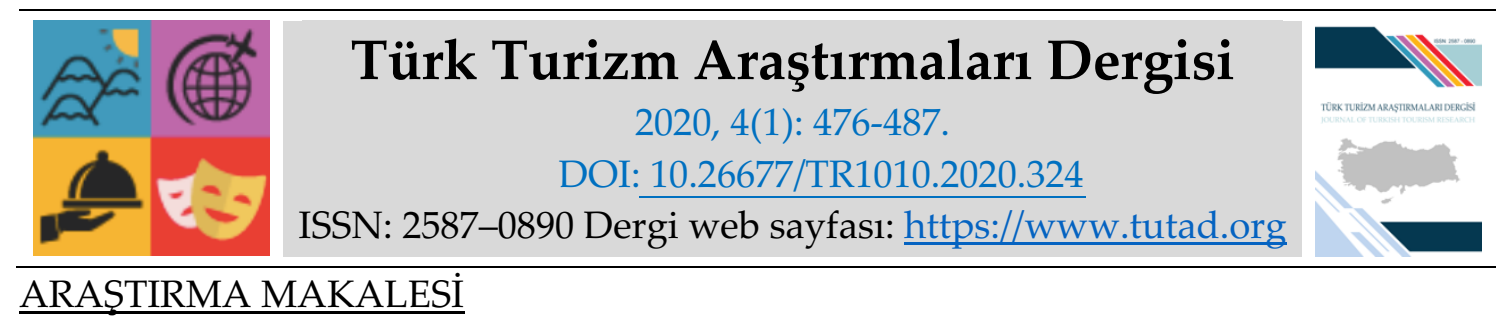

\title{
Turizm Öğrencilerinin Engelli Bireylere ve Engelli Turizmine Bakış Açılarını Belirlemeye Yönelik Bir Araştırma
}

Dr. Öğr. Üyesi Seyit Ahmet SOLMAZ, Harran Üniversitesi, Turizm ve Otel İşletmeciliği Yüksekokulu, Şanlıurfa, e-posta: seyitahmetsolmaz@harran.edu.tr

ORCID: https://orcid.org/0000-0002-7224-3605

Dr. Öğr. Üyesi Emirhan YENIŞEHIIRLİĞLU, Alanya Alaaddin Keykubat Üniversitesi, Turizm Fakültesi, Alanya, e-posta: emirhan.yenisehirlioglu@alanya.edu.tr

ORCID: https://orcid.org/0000-0002-6856-9506

Öz

Engelli turizmi pazarı Avrupa'da sürekli bir gelişim göstermektedir. Türkiye'de de turizme katılan engelli bireylerin sayısı artmaktadır. Sosyal turizm kapsamında da değerlendirilebilecek bu turizm türünün gelişmesi, geleceğin yönetici adaylarının engelli bireylere ve engelli turizmine pozitif bir bakış sergilemesi ile daha olanaklı hale gelecektir. Bu araştırmanın amacı, turizm eğitimi alan yükseköğrenim öğrencilerinin engelli bireylere ve engelli turizmine bakış açılarını tespit etmektir. $\mathrm{Bu}$ amaçla bir saha çalışması gerçekleştirilmiştir. Araştırmanın evreninin Türkiye'deki tüm turizm eğitimi alan öğrenciler oluşturmaktadır. Araştırma örneklemini ise kolayda örnekleme yöntemiyle seçilmiş, Türkiye'nin muhtelif turizm okullarında ön lisans ve lisans düzeyinde turizm öğrenimi gören 542 öğrenci oluşturmaktadır. Araştırmadan elde edilen veriler istatistiksel yöntemler kullanılarak ve paket program yoluyla analiz edilmiştir. Araştırmadan elde edilen bulgular, turizm öğrencilerinin engelli bireylere ve engelli turizmi pazarına pozitif baktığını ortaya koymaktadır. Aynı zamanda öğrencilerin geliştirdikleri bakış açısı cinsiyet, öğrenim durumları ve engellilere hizmet edip etmeme durumlarına göre anlamlı farkl1lıklar göstermektedir.

Anahtar Kelimeler: Engellilik, Engelli Bireyler, Engelli Turizmi, Engelli Turizmi Pazarı, Turizm. Makale Gönderme Tarihi: 22.10.2019

Makale Kabul Tarihi: 10.01.2020

\section{Önerilen Atıf:}

Solmaz, S. A. ve Yenişehirlioğlu, E. (2020). Turizm Öğrencilerinin Engelli Bireylere ve Engelli Turizmine Bakış Açılarını Belirlemeye Yönelik Bir Araştırma, Türk Turizm Araştırmaları Dergisi, 4(1): 476-487.

(c) 2020 Türk Turizm Araştırmaları Dergisi. 


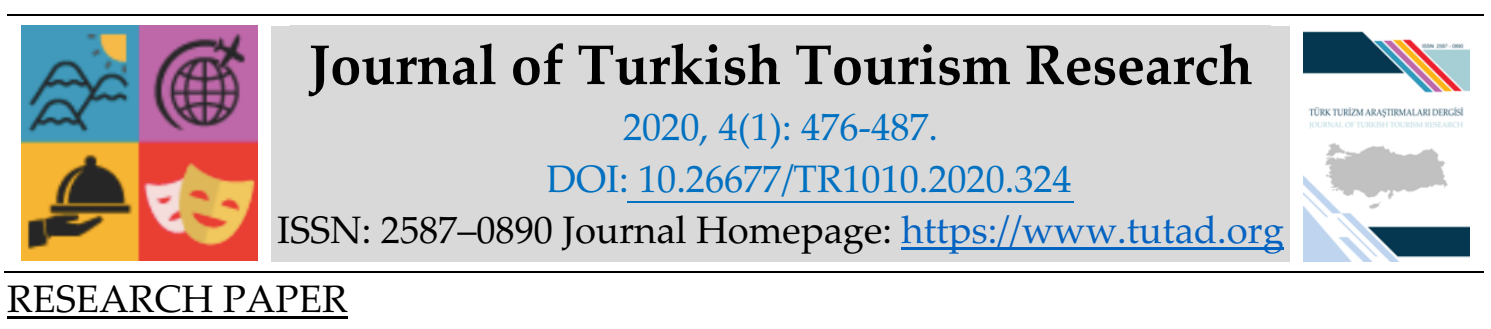

\title{
A Research on Determining the Perspectives of Tourism Students on Disabled Individuals and Disabled Tourism
}

Assistant Prof. Dr. Seyit Ahmet SOLMAZ, Harran University, School of Tourism and Hotel Management, Şanlıurfa, e-mail: seyitahmetsolmaz@harran.edu.tr ORCID: https://orcid.org/0000-0002-7224-3605

Assistant Prof. Dr. Emirhan YENIŞEHIRLIOĞLU, Alanya Alaaddin Keykubat University, Faculty of Tourism, Alanya, e-mail: emirhan.yenisehirlioglu@alanya.edu.tr

ORCID: https://orcid.org/0000-0002-6856-9506

\begin{abstract}
The disabled tourism market is developing continuously in Europe. Turkey also is increasing the number of individuals with disabilities who participated in tourism. The development of this type of tourism, which can be evaluated within the scope of social tourism, will become more feasible with the prospective managers of the future having a positive view on disabled individuals and disabled tourism. The aim of this study is to determine the perspectives of higher education students in tourism education towards disabled individuals and disabled tourism. For this purpose, a field study was carried out. All tourist areas in Turkey training of research students constitutes the universe. In the study sample selected by sampling method easy, Turkey's tourism schools in various undergraduate and graduate level education constitutes 542 students of tourism. The data obtained from the research were analyzed using statistical methods and software. The findings of the study show that tourism students have positive views on disabled individuals and disabled tourism market. At the same time, students' perspectives show significant differences according to gender, educational background and disability status.
\end{abstract}

Keywords: Disability, Disabled Individuals, Disabled Tourism, Disabled Tourism Market, Tourism.

Received: 22.10 .2019

Accepted: 10.01 .2020

\section{Suggested Citation:}

Solmaz, S. A. and Yenişehirlioğlu, E. (2020). A Research on Determining the Perspectives of Tourism Students on Disabled Individuals and Disabled Tourism, Journal of Turkish Tourism Research, 4(1): 476-487.

(c) 2020 Türk Turizm Araştırmaları Dergisi. 


\section{Gíriş}

Tarih sayfalarına bakıldığında, engelli bireylerin zaman ve coğrafyadan bağımsız olarak toplumlar tarafından dışlandığına dair onlarca örnek karşımıza çıkmaktadır. Ortaçağda engelli bireylerin içlerindeki kötülüklerin dışlarına yansıdığı kabul edilerek öldürüldükleri (Akın, 2001), II. Dünya savaşı esnasında toplama kamplarında engelli bireylerin doğrudan katledildiği (Mitchell ve Snyder, 2003: 859), 1960'lı yıllarda ise Chicago şehrinin sokaklarına engelli bireylerin evlerinden dışarı çıkarak sosyal hayata karışmalarına engel olmak için "kötürüm, engelli ya da benzer bozukluğu olan kimseler sokaklarda dolaşamaz, halka kendini gösteremez ve kamu alanlarından yararlanamaz" şeklinde ikaz panoları yerleştirildiği bilinmektedir (Kitchin 1998 :350).

Maalesef ki yaşanılan sosyal dışlanma sadece tarih sayfalarında ortaya çıkan bir kavram olmaktan oldukça uzaktır. Halen Çin Halk Cumhuriyeti'nde ultrason esnasında bebeğin engelli doğacağı anlaşıldığı an ailenin rızası olsun ya da olmasın yasa kapsamında bebeğin alınması gerekmektedir. Aynı şekilde engelli çocuk doğurma ihtimali olan ailelerin kısırlaştırılması da bu yasa kapsamına ele alınan bir diğer konudur (Sherry, 2004).

Türkiye'de engelli bireylerin kamusal alanlardan dışlanabildiği ve insanların engelli bireylerden kendilerini ve çocuklarını uzak tutmak isteyebildikleri de yapılan araştırmalar ile ortaya koyulmuştur (Baykoç vd. 1998, Özbaba, 2000, Eryılmaz, 2010). Özellikle spesifik olarak Turizm endüstrisini ele alan araştırmalarda ise; engelli bireylerin turist veya çalışan olarak kısmen kabul gördüğü ancak halen "sosyal dışlanma" etmenlerinin endüstrinin farklı katmanlarında yüksek düzeyde varlığını sürdürdügü tespit edilmiştir (Yenişehirlioğlu ve Türkay, 2013).

Diğer endüstrilerde olduğu gibi Turizm endüstrisinin geleceği de yeni nesillerin elindedir. Bu bağlamda Turizm öğrencilerinin konuya bakışının tespit edilmesi endüstrinin geleceğinde engelli bireylerin konumlanabilmeleri açısından önem arz etmektedir.

\section{ENGELLİ KAVRAMI VE TÜRLERİ}

Engelliğin tanımı 5378 sayılı ve 1.7.2005 tarihli Özürlüler ve Bazı Kanun ve Kanun Hükmünde Kararnamelerde Değişiklik Yapılması Hakkında Kanun'un 3/a maddesinde “Doğuştan veya sonradan herhangi bir nedenle bedensel, zihinsel, ruhsal, duyusal ve sosyal yeteneklerini çeşitli derecelerde kaybetmesi nedeniyle toplumsal yaşama uyum sağlama ve günlük gereksinimlerini karşılama güçlükleri olan ve korunma, bakım, rehabilitasyon, danışmanlık ve destek hizmetlerine ihtiyaç duyan kişiler" şeklinde tanımlanmıştır. Bu bağlamda engelliliğin farklı türleri olduğu anlaşılabilmektedir.

Engelli bireyler Koca'ya göre (2016) aşağıdaki 5 şekilde incelenebilmektedir:

- Zihinsel Engelliler

- Görme Engelliler

- İşitme ve Konuşma Engelliler

- Ortopedik Engelliler

- Süreğen Engelliler

Engelliliğin farklı türlerinden bahsedilebileceği gibi seviyesinden de bahsedilmesi önemlidir. Örneğin ortopedik bir engel günlük hayata hiçbir negatif dışsallık yaratmayacak şekilde bireyde var olabilirken aynı engel türü kişiyi yatalak edebilecek kadar üst seviyelerde de seyredebilir. Bu bağlamda engelliliğin hafif seyri ile ağır seyri kişinin sosyal hayat ile olan teması açısından bir göstergedir. 
Günümüzde engelli bireylerin dünya nüfusunun ortalama \%15'ini oluşturdukları (WHO, 2011), bu oranın ise 750 milyon kişiye tekabül ettiği ifade edilmektedir. TUIK 2018 verilerine baktığımızda Türkiye nüfusu ortalama 81,9 milyon olarak verilmekte bu durum da ülkemizdeki ortalama her 9 kişiden birinin engelli olduğu anlamına gelmektedir. Yine TUİK tarafından yayınlanan istatistiklere göre Türkiye' de 8,5 milyonu aşkın engelli bulunmaktadır. Verilerden de anlaşılabileceği gibi Engellilik sadece bireylerin yaşadığı özel bir durum olmaktan ziyade Sosyal Devlet yapısını doğrudan ilgilendiren bir gerçekliktir. Yapılan araştırmalar engelli bireyler ile sağlıklı bireyler arasında ki eşitliğin sağlaması devletin görevi olarak ifade edilmektedir (Okur ve Erdugan, 2010: 254). Bu ifadeyi destekler şekilde engellilik kavramının Sosyal modeline göre engellilik; bireysel eksiklikler sebebiyle değil, engellilerin yaşadığı toplumun çözüm üretememesi neticesinde ortaya çıkmaktadır (Arıkan, 2002).

\section{ENGELLİ BIIREYLER VE TURİM ENDÜSTRİSI}

İnsanlar ile diğer canlı türleri arasındaki en belirgin fark; sistematik düşünme ve kitlesel hareket edebilme yetisidir. Bu yeti birbirini hiç tanımayan insanların belirli bir amaç için bir araya gelebilmesine olanak tanımaktadır (Harari 2016). Kanada'da yaşayan bir bireyin hayatında hiç tanışmadığı ve muhtemelen asla tanışamayacağı bir Afrikalıya gıda yardımı göndermesi bu kitlesel hareketin ve sistematik düşüncenin bir örneği olarak gösterilebilir. Turizm endüstrisinde engelli bireyler söz konusu olduğunda ayn sistematik düşünme yetisi bizlere engelli bireylerin bu endüstrinin bir parçası olabilmeleri için ihtiyaç duydukları sosyal ve fiziksel altyapıları sağlamamızı söylemektedir.

Turizm endüstrisinin yasal altyapısında bu konuya yönelik çalışmalar 80'li yıllarda başlamıştır. Örneğin 1982 tarihli 2634 sayılı Turizmi Teşvik Yasasında "80 odadan fazla odaya sahip tatil köyleri ve otellerde oda sayısının en az \%1'ine tekabül edecek şekilde engelliler için özel olarak tasarlanmış oda bulunması gerekmektedir" şeklinde bir düzenleme bulunmaktadır. Bu bağlamda turizm endüstrisinin bel kemiği kabul edilen konaklama işletmelerinde engelli turistlerin ihtiyaçlarını karşılayabilecek altyapı hizmetlerinin var olduğu ifade edilebilir. Aksi durum söz konusu olsa bile fiziksel altyapı eksiklikleri çok kısa sürede, maddi yatırımlar ile çözülebilmektedir.

Çözülmesi zor olan esas problem insanların zihninde yatan engelli birey algısıdır. Özellikle turizm hareketlilikleri söz konusu olduğunda engelli bireyler ile temas etmekten kaçınan, tatil süreleri boyunca engelli birey görmekten rahatsızlık duyacağını belirten kişilerin var oldukları daha önceki çalışmalarda elde edilen bulgular arsındadır (Yenişehirlioğlu ve Türkay, 2013).

\section{ARAŞTIRMANIN METODOLOJİSi}

Avrupa'da yaşayan engelli bireylerin \%71'i seyahat faaliyetini gerçekleştirmektedir. Bunların 8 milyonu seyahatlerinde yurt dışını tercih etmektedir. 15 milyon engelli birey ise iç turizm faaliyetlerine katılmakta, 22 milyonu ise şehir turlarına katılmaktadır. Sonuç olarak; Avrupa'da ortalama 35 milyon engelli birey seyahat etmektedir ve yıllık 650 milyon geceleme oluşturmaktadır (Guerra, 2003: 1197). Avrupa için önemli bir turistik destinasyon olan Türkiye'nin de engelli turizmi pazarından pay alabilmesi, öncelikle bu pazarı önemsemek ve bunun için gerekli şartları hazırlamakla mümkün olacaktır. Bunun için öncelikle turizm yöneticilerinin engelli turizm pazarına ve engellilere pozitif bakış açısına sahip olmaları gerekmektedir. Bu araştırmada geleceğin turizm yöneticileri olan turizm öğrencilerinin engelli bireylere ve engelli turizmine bakış açıları tespit edilmeye çalışılmıştır. 
Bu amaçla Türkiye'nin muhtelif meslek yüksekokulları, turizm fakülteleri ile turizm ve otel işletmeciliği yüksekokullarında eğitim gören öğrencilere anket uygulanmak suretiyle bir alan araştırması gerçekleştirilmiştir. Araştırmanın evrenini Türkiye'de ön lisans ve lisans düzeyinde turizm eğitimi alan öğrenciler oluşturmaktadır. Bu kapsamda eğitim alan öğrenci sayısının 40.000 'in üzerindedir (istatistik.yok.gov.tr). Araştırmanın örneklemini ise kolayda örnekleme yöntemiyle seçilmiş 542 öğrenci meydana getirmektedir. Örneklem büyüklüğü ile ilgili kesin yargılar ileri sürülemeyeceği literatürde ifade edilmekle birlikte pek çok araştırma için 30 ila 500 arasında örneklem büyüklüklerinin yeterli olduğu belirtilmektedir (Altunışık vd., 2007: 127). Anket formları öğrencilere yüz yüze uygulanmıştır.

Araştırmada kullanılan anket formu 3 bölümden meydana gelmektedir. Birinci bölümde turizm öğrencilerinin engelli bireylere bakışını belirlemeye yönelik 12 ifade yer almaktadır. İkinci bölümde ise turizm öğrencilerinin engelli turizmi pazarına bakış açılarını belirlemek üzere 27 ifade bulunmaktadır. Bu kısımdaki ifadeler 5'li Likert ölçeğine göre derecelendirilmiştir. İfadeler en olumsuzdan (1) Kesinlikle Katılmıyorum, en olumluya doğrudur (5) Kesinlikle katılıyorum. Araştırmada ölçek güvenilirliği belirlemek amacıyla yaygın olarak kullanılan bir yöntem olan Cronbach Alfa katsayısına bakılmıştır. Ölçekte yer alan 39 ifade için hesaplanan Cronbach Alfa katsayısı 0,851'dir. Bu değer, ölçeğin yüksek derecede bir içsel tutarlılı̆̆a sahip olduğunu göstermektedir (Kayış, 2010: 405).

Araştırma kapsamında elde edilen veriler, bilgisayar ortamında istatistiksel paket program (SPSS) kullanılarak analiz edilmiştir. Öncelikle örneklemi oluşturan turizm öğrencilerine ilişkin özelliklerin aktarılmasında frekans analizinden yararlanılmıştır. Daha sonra ölçeğin yapısal geçerliliğini test etmek ve ifadeleri daha az sayıda boyut altında toplamak için faktör analizinden, ardından faktör analizinde ortaya çıkan boyutlarda öğrencilerin özelliklerine göre bir farklılaşma olup olmadığının belirlenmesinde ise bağımsız örneklem t-testinden faydalanılmıştır. Elde edilen bulgular ve bulgulara ilişkin yorumlar aşağıda aktarılmıştır.

\section{BULGULAR VE YORUM}

Araştırmaya katılan öğrencilerin cinsiyete göre dağılımlarına bakıldığında, birbirine yakın olduğu gözlenmektedir. Sınıflar itibariyle dağılımda ise 1. ve 2. Sınıf öğrencilerinin ağırlıkta olduğu anlaşılmaktadır. 4. Sınıf öğrencilerinin oranı ise yalnızca \%5,3'tür. Örneklem içinde lisans düzeyinde turizm eğitimi alan öğrencilerin daha fazladır (\%71,0). Bunu \% 29'luk oranla ön lisans turizm öğrencileri takip etmektedir. Araştırmaya katılan öğrencilerin \%59,9'u henüz zorunlu stajlarını gerçekleştirmemiş öğrencilerden meydana gelmektedir. Araştırmaya katılan öğrencilerin \%68,1'i engelli bir tanıdığının olduğunu belirtmiştir. Bu durum engellilere karşı bakış konusunda sağlıklı bilgilerin alınması noktasında bir avantaj olarak düşünülebilir. Daha önce bir engelliye hizmet eden öğrencilerin oranı ise \%26,3'tür.

Ölçeğin yapısal geçerliliğini test etmek ve ifadeler daha az sayıda boyut altında toplamak için faktör analizi gerçekleştirilmiştir. Faktör analizi, birbirleriyle ilişkili çok sayıdaki değişkeni az sayıda, anlamlı ve birbirinden bağımsız faktörlere halinde getiren ve yaygın olarak kullanılan çok değişkenli istatistik tekniklerinden biridir (Kalaycı, 2010: 321). Faktör analizi öncesinde veri setinin faktör analizine uygunluğu değerlendirilmiştir. Bu bağlamda öncelikle veri setinin basıklık-çarpıklık değerleri incelenmiş -2 ile +2 arasında değer aldığı görülmüştür. Aynı zamanda mod, medyan ve aritmetik ortalama dağılımları da birbirine yakındır. Bu değerler, verilerin normal dağılım koşulunu sağladığını göstermektedir. Diğer yandan verilerin faktör analizi için uygunluğun değerlendirilmesinde KMO değeri ile Barlett test sonucu da incelenmiştir. Engelli bireylere bakış ölçeği için KMO örneklem yeterliliği değeri \%90,8'dir. Bu değer, mükemmel 
olarak değerlendirilmektedir (Kalaycı, 2010: 322). Barlett küresellik testi sonucu da anlamlıdır $(p<0,05)$. Bu değerler ölçeğin faktör analizine uygunluğunu göstermektedir. Engelli bireylere bakış ölçeğine ilişkin faktör analizi sonuçları Tablo 2' de gösterilmektedir.

Tablo 1. Katılımcılara İlişkin Demografik Özellikler

\begin{tabular}{|l|l|c|c|}
\hline \multicolumn{2}{|c|}{ DEMOGRAFIK BILLIILER } & N & \% \\
\hline \multirow{3}{*}{ Cinsiyet } & Erkek & 261 & 49,4 \\
\cline { 2 - 4 } & Kadın & 267 & 50,6 \\
\hline \multirow{4}{*}{ Sınıf } & 1. Sınıf & 205 & 39,0 \\
\cline { 2 - 4 } & 2. Sinıf & 172 & 32,7 \\
\cline { 2 - 4 } & 3. Sinıf & 121 & 23,0 \\
\cline { 2 - 4 } & 4. Sinıf & 28 & 5,3 \\
\hline \multirow{3}{*}{ Eğitim } & Ön Lisans & 151 & 29,0 \\
\cline { 2 - 4 } & Lisans & 369 & 71,0 \\
\hline \multirow{3}{*}{ Staj Yaptınız mı? } & Evet & 210 & 40,1 \\
\cline { 2 - 4 } & Hayır & 314 & 59,9 \\
\hline \multirow{3}{*}{ Engelli Bir tanıdığınız var mı? } & Evet & 358 & 68,1 \\
\cline { 2 - 4 } & Hayır & 168 & 31,9 \\
\hline \multirow{2}{*}{$\begin{array}{c}\text { Daha önce engelli bir turiste hizmet } \\
\text { verdiniz mi? }\end{array}$} & Evet & 139 & 26,3 \\
\cline { 2 - 4 } & Hayır & 389 & 73,7 \\
\hline
\end{tabular}

Tablo 2. Engelli Bireylere Bakış Ölçeğine İlişkin Faktör Analizi Sonuçları

\begin{tabular}{|c|c|c|c|c|c|}
\hline \multicolumn{5}{|l|}{ FAKTÖR BOYUTLARI } & \multirow{3}{*}{$\begin{array}{l}\text { Faktör } \\
\text { Yükü }\end{array}$} \\
\hline \multirow{2}{*}{ ENGELLİ BİREYLERE POZITIF BAKIŞ } & Özdeğer & Aç. Varyans & Art. Ort. & Cr. Alfa & \\
\hline & 3,415 & 37,945 & 4,5697 & 0,853 & \\
\hline \multicolumn{5}{|c|}{ Engellilere toplumsal hayatın her alanında gereken önem verilmelidir. } & ,793 \\
\hline \multicolumn{5}{|c|}{ Çalıştığım işyerinde engelli bir çalışan olsa ona elimden gelen yardımı yaparım. } & ,790 \\
\hline \multicolumn{5}{|c|}{ Engellilerle ilgilenmenin en iyi yolu, onları toplumun doğal bir parçası olarak görmektir. } & ,774 \\
\hline \multicolumn{5}{|c|}{ Çalıştığım işyerinde engelli bireylerle çalışmaktan çekinmem. } & ,748 \\
\hline \multicolumn{5}{|c|}{ Engelli bir bireyle buluştuğumda, onun yemek yemesine yardımcı olmaktan çekinmem. } &, 570 \\
\hline \multicolumn{5}{|c|}{ Engelli birisiyle bir araya geldiğimde diğer insanların ne düşündüğünü önemsemem. } &, 523 \\
\hline \multirow{2}{*}{ ENGELLİ BİREYLERLE İLIŞKİ } & Özdeğer & Aç. Varyans & Art. Ort. & Cr. Alfa & \\
\hline & 2,159 & 23,988 & 4,1236 & 0,661 & \\
\hline \multirow{3}{*}{\multicolumn{5}{|c|}{$\begin{array}{l}\text { Engelli birisini çok sevsem, onunla evlenmek isterdim. } \\
\text { Engellik durumunu dikkate almaksızın, engelli bir bireyle yakın arkadaşlık ilişkisi } \\
\text { kurarım. } \\
\text { Engelli bir bireyle arkadaşlık kurmak isterim. }\end{array}$}} & ,811 \\
\hline & & & & & 712 \\
\hline & & & & & ,597 \\
\hline
\end{tabular}

Varimaks Rotasyonlu Temel Bileşenler Analizi: Açılanan Toplam Varyans: \%61,933; Kaiser-MeyerOlkin Örneklem Yeterliliği: \%90,8; Barlett's Küresellik Testi: p<0,001; Ki-Kare: 6940,179; df: 36; Değerlendirme Aralı̆̆ı: (1) Kesinlikle Katılmıyorum - (5) Kesinlikle Katılıyorum. 
Faktör analizi neticesinde engelli bireylere bakış ölçeğinin iki boyut etrafında şekillendiği anlaşılmaktadır (Tablo 2). Bu iki boyut tarafından açıklanan toplam varyans ise $\% 61,9^{\prime}$ dur. Birinci boyutun özdeğeri 3,415'tir. Birinci boyutun açıkladığı varyans ise 37,945'tir. Engelli bireylere yardımcı olma ve onlara gereken özeni gösterme ile ilgili ifadelerin yer aldığı bu boyut, engelli bireylere pozitif bakış olarak isimlendirilmiştir. Boyutun aritmetik ortalamasına bakıldığında, turizm öğrencilerinin engelli bireylere gerçek anlamda pozitif baktığı, onlarla aynı işyerinde çalışmaktan çekinmeyeceği ve ellerinden gelen her türlü yardım ve desteği yapabilecekleri anlaşılmaktadır (Tablo 2). Bu bakış açısı, engellilerin de bu toplumun bir parçası olduklarını ve her bireyin bir engelli adayı olabileceğini unutmamaları açısından sevindiricidir. İkinci boyut engellilerle ilişki olarak adlandırılmıştır. Bu boyutun açıkladığı varyans, \% 23,988'dir. Boyut aritmetik ortalaması, turizm öğrencilerinin engellilerle arkadaşlık kurması ile ilgili ifadelere katılım gösterdiklerini göstermektedir $(4,1236)$. Ancak bu boyutun aritmetik ortalaması diğer boyuta göre $(4,5697)$ nispeten daha düşüktür. Bu bulgu, engelli bireylerle ilişki kurma noktasında turizm öğrencilerinin biraz daha çekingen davrandıklarını ortaya koymaktadır.

Tablo 3. Engelli Turizmine Bakış Ölçeğine İlişkin Faktör Analizi Sonuçları

\begin{tabular}{|c|c|c|c|c|c|}
\hline \multicolumn{5}{|l|}{ FAKTÖR BOYUTLARI } & \multirow[b]{2}{*}{$\begin{array}{r}\text { Faktör } \\
\text { Yükü }\end{array}$} \\
\hline Engelli Turizmini Teşvik & $\begin{array}{c}\text { Özdeğer } \\
2,856 \\
\end{array}$ & $\begin{array}{c}\text { Aç. Varyans } \\
15,029\end{array}$ & $\begin{array}{c}\text { Art. Ort. } \\
4,4739 \\
\end{array}$ & $\begin{array}{c}\text { Cr. Alfa } \\
0,829 \\
\end{array}$ & \\
\hline \multicolumn{5}{|c|}{ Ülkemizde engelli bireylere hizmet verebilecek daha fazla otel inşa edilmelidir. } & ,799 \\
\hline \multicolumn{5}{|c|}{ Engelli bireylerin turizme katılmaları için yerel yönetimler ve diğer kuruluşlar özendirici tedbirler almalıdır. } & ,781 \\
\hline \multicolumn{5}{|c|}{ Engellilerin seyahate katılmaları için daha fazla adımlar atılmalıdır. } & ,777 \\
\hline \multicolumn{5}{|c|}{ Turizm merkezlerinin çevresel düzenlemeleri engelliler için uygundur. } & 625 \\
\hline \multirow{2}{*}{ Engelli Turizmi Pazarına Bakış } & Özdeğer & Aç. Varyans & Art. Ort. & Cr. Alfa & \\
\hline & 2,353 & 12,385 & 4,1083 & 0,709 & \\
\hline \multicolumn{5}{|l|}{ Engelli turistlere ayrım yapılmamalıdır. } & 676 \\
\hline \multicolumn{5}{|c|}{ Engelli pazarı ülkemiz için önemli bir pazardır. } & 637 \\
\hline \multicolumn{5}{|c|}{ Engelli turistlere hizmet vermekten gurur duyarım. } & 625 \\
\hline \multicolumn{5}{|c|}{ Ülkemizde yalnızca engellilerin katılacağı festivaller düzenlenmelidir. } &, 589 \\
\hline \multicolumn{5}{|c|}{ Engelli turistler için ülkemizde daha fazla turizm işletmesi açılmalıdır. } &, 514 \\
\hline \multirow{2}{*}{ Engelli Turizminin Olumsuzlukları } & Özdeğer & Aç. Varyans & Art. Ort. & Cr. Alfa & \\
\hline & 1,916 & 10,082 & 4,2513 & 0,694 & \\
\hline \multicolumn{5}{|c|}{ Engelli insanlara bakış açım turizm eğitimi almaya başladıktan sonra değişti. } & ,779 \\
\hline \multicolumn{5}{|c|}{ Engellilerle birlikte tatil yapmak diğer turistlere rahatsızlık verebilir. } & 600 \\
\hline \multicolumn{5}{|l|}{ Engelli turistler daha alıngandır. } & 464 \\
\hline \multirow{2}{*}{ Engelli Turistlere Hizmet Etme } & Özdeğer & Aç. Varyans & Art. Ort. & Cr. Alfa & \\
\hline & 1,587 & 9,775 & 3,5606 & 0,690 & \\
\hline \multirow{4}{*}{\multicolumn{5}{|c|}{$\begin{array}{l}\text { Engelli turistlerle anlaşmak daha kolaydır. } \\
\text { Engelli müşteriye hizmet verecek kadar yeterli bilgiye sahip olduğumu düşünüyorum. } \\
\text { Hafif engellilere hizmet etmek ağır engellilere hizmet etmekten arasında bir fark yoktur. } \\
\text { Engelli turistlere hizmet sunulurken daha hassas davranılmalıdır. }\end{array}$}} & ,745 \\
\hline & & & & & 672 \\
\hline & & & & &, 578 \\
\hline & & & & & ,464 \\
\hline \multirow{2}{*}{ Engelli Turistlerin Farklılıkları } & Özdeğer & Aç. Varyans & Art. Ort. & Cr. Alfa & \\
\hline & 1,836 & 9,666 & 3,4865 & 0,658 & \\
\hline \multirow{3}{*}{\multicolumn{5}{|c|}{$\begin{array}{l}\text { Engelliler daha farklı kişilik özelliklerine sahipler. } \\
\text { Engelli turistlerin güvenlik gereksinimleri diğer turistlere göre daha fazladır. } \\
\text { Engelli turistler de diğer turistler gibi turizme katılma hakkına sahiptir. }\end{array}$}} & ,759 \\
\hline & & & & & 731 \\
\hline & & & & &, 573 \\
\hline
\end{tabular}


Varimaks Rotasyonlu Temel Bileşenler Analizi: Açılanan Toplam Varyans: \% 56,937; KaiserMeyer-Olkin Örneklem Yeterliliği: \%90,8; Barlett's Küresellik Testi: $p<0,001$; Ki-Kare: 6940,179; df: 36; Değerlendirme Aralı̆̆ı: (1) Kesinlikle Katılmıyorum - (5) Kesinlikle Katılıyorum.

Engelli turizmine bakış ölçeğine ilişkin faktör analizi sonuçları Tablo 3'te aktarılmaktadır. Faktör analizi sonucunda engelli turizmine bakış ölçeği, beş boyut etrafında toplanmıştır. Bu beş

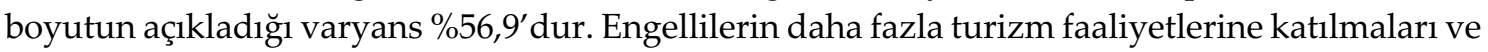
onlara yönelik özendirici tedbirlerin alınmasına yönelik ifadelerin yer aldığ turizmini teşvik olarak isimlendirilmiştir. Boyutun özdeğeri 2,856, açıladığ1 varyans ise 15,029 ' dur. Boyut aritmetik ortalaması incelendiğinde, bu beş boyut arasında en yüksek katılımın gösterildiği boyut olarak dikkat çekmektedir. Turizm öğrencilerinin engelli turizmi pazarının gelişmesine yönelik istekliliği gelecek açısından umut vadetmektedir.

İkinci boyut doğrudan engelli turizmi pazarına yönelik ifadelerin yer aldığı boyuttur. "Engelli pazarı ülkemiz için önemli bir pazardır", "Engelli turistler için ülkemizde daha fazla turizm işletmesi açılmalıdır." gibi ifadelerin yer aldığı bu boyutun aritmetik ortalaması, 4,1083'tür. Bu değer, turizm öğrencilerinin engelli turizmi pazarına pozitif bir yaklaşım içinde olduklarını göstermektedir.

Tablo 2'ye bakıldığında, engelli bireylere hizmet etme noktasında turizm öğrencilerinin çekimser oldukları görülmektedir. Öyle ki engellilere hizmet etme boyutunun aritmetik ortalaması 3,5606'dır. Bu durum, engellilere hizmet konusundan tecrübesiz olmalarından veyahut daha hassas davranmalarının bilincinde olmalarından kaynaklanabilir. Boyutlar itibariyle ifadelere en düşük katılımın gösterildiği boyut beşinci boyuttur. Bu boyut, engelli turistlerin farklılıklarına yönelik ifadeler içermektedir. Ancak turizm öğrencileri, engellilerin de normal bireyler gibi olduğunu düşünmekte ve bu ifadelere düşük katılım göstermektedirler. Engelli bireylere bakış ve engelli turizm pazarına bakış ölçeklerinde yer alan boyutlarda turizm öğrencilerinin demografik özelliklerine göre farklılaşmaların olup olmadığının tespiti için farklılık analizi olan t-testinden yararlanılmıştır. İlk olarak öğrencilerin cinsiyetlerine göre boyutlarda bir farklılık olup olmadığı incelenmiştir. Buna ilişkin bulgular Tablo 4 'te aktarılmıştır.

Tablo 4. Engelli Bireylere ve Engelli Turizmine Bakış Boyutlarının Cinsiyete Göre Farklılaşması

\begin{tabular}{|c|c|c|c|c|c|c|}
\hline Boyutlar & Değişken & $\begin{array}{c}\text { Aritmetik } \\
\text { Ortalama }\end{array}$ & $\begin{array}{c}\text { Standart } \\
\text { Sapma }\end{array}$ & $\begin{array}{l}\text { Ortalama } \\
\text { Farkı }\end{array}$ & t Değeri & Anlamlılık \\
\hline \multirow{2}{*}{$\begin{array}{l}\text { Engelli Bireylere } \\
\text { Pozitif Bakış }\end{array}$} & Erkek & 4,5109 & ,63277 & \multirow{2}{*}{0,1073} & \multirow{2}{*}{3,814} & \multirow{2}{*}{, $000^{*}$} \\
\hline & Kadın & 4,6183 &, 58246 & & & \\
\hline \multirow{2}{*}{ Engelli Bireylerle İlişki } & Erkek & 4,1311 & 75078 & \multirow{2}{*}{0,0141} & \multirow{2}{*}{0,420} & \multirow{2}{*}{ 675 } \\
\hline & Kadın & 4,1170 & 69943 & & & \\
\hline \multirow{2}{*}{$\begin{array}{l}\text { Engelli Turizmini } \\
\text { Teşvik }\end{array}$} & Erkek & 4,4223 & 64889 & \multirow{2}{*}{0,0976} & \multirow{2}{*}{3,316} & \multirow{2}{*}{, $001^{*}$} \\
\hline & Kadın & 4,5199 & ,62200 & & & \\
\hline \multirow{2}{*}{$\begin{array}{l}\text { Engelli Turizmi } \\
\text { Pazarına Bakış }\end{array}$} & Erkek & 4,0243 & 70518 & \multirow{2}{*}{0,1598} & \multirow{2}{*}{4,956} & \multirow{2}{*}{, $000^{*}$} \\
\hline & Kadın & 4,1841 & ,68714 & & & \\
\hline \multirow{2}{*}{$\begin{array}{l}\text { Engelli Turizminin } \\
\text { Olumsuzlukları }\end{array}$} & Erkek & 4,2065 & ,77154 & \multirow{2}{*}{0,0769} & \multirow{2}{*}{2,202} & \multirow{2}{*}{, $028^{*}$} \\
\hline & Kadın & 4,2834 & ,73676 & & & \\
\hline \multirow{2}{*}{$\begin{array}{l}\text { Engelli Turistlere } \\
\text { Hizmet Etme }\end{array}$} & Erkek & 3,5692 & ,72034 & \multirow{2}{*}{0,0153} & \multirow{2}{*}{0,469} & \multirow{2}{*}{,639 } \\
\hline & Kadın & 3,5539 & ,68912 & & & \\
\hline \multirow{2}{*}{$\begin{array}{l}\text { Engelli Turistlerin } \\
\text { Farklılıkları }\end{array}$} & Erkek & 3,5115 & ,87162 & \multirow{2}{*}{0,0524} & \multirow{2}{*}{1,298} & \multirow{2}{*}{ 194 } \\
\hline & Kadın & 3,4590 & ,87279 & & & \\
\hline
\end{tabular}

${ }^{*} p<0,05$ düzeyinde anlamlıdir. 
Engelli bireylere pozitif bakış, engelli turizmini teşvik, engelli turizmi pazarına bakış ve engelli turizminin olumsuzlukları boyutlarında cinsiyete göre istatistiksel olarak anlamlı farklılıklar tespit edilmiştir. Bütün boyutların aritmetik ortalamalarına bakıldığında kadınların erkeklere göre daha yüksek ortalamalara sahip olduğu görülmektedir. Öyle ki kadınlar, engelli bireylere erkeklere göre daha pozitif bakmaktadır. Engelli turizmine bakış açılarının da erkeklere oranla daha pozitif olduğu anlaşılmaktadır (Tablo 4). Bu durum kadınların doğurganlık yetenekleri gereği daha duygusal ve korumacı bir yapıya sahip olmaları ile açıklanabilir.

Tablo 5. Engelli Bireylere ve Engelli Turizmine Bakış Boyutlarının Eğitim Düzeyine Göre Farklılaşması

\begin{tabular}{|c|c|c|c|c|c|c|}
\hline Boyutlar & Değişken & $\begin{array}{c}\text { Aritmetik } \\
\text { Ortalama }\end{array}$ & $\begin{array}{c}\text { Standart } \\
\text { Sapma }\end{array}$ & $\begin{array}{l}\text { Ortalama } \\
\text { Fark1 }\end{array}$ & t Değeri & Anlamlılık \\
\hline \multirow{2}{*}{$\begin{array}{l}\text { Engelli Bireylere } \\
\text { Pozitif Bakış }\end{array}$} & Ön Lisans & 4,6291 & ,50398 & \multirow{2}{*}{0,0843} & \multirow{2}{*}{2,621} & \multirow{2}{*}{, $009^{*}$} \\
\hline & Lisans & 4,5448 & 63877 & & & \\
\hline \multirow{2}{*}{$\begin{array}{l}\text { Engelli Bireylerle } \\
\text { İlişki }\end{array}$} & Ön Lisans & 4,1165 & 68769 & \multirow{2}{*}{0,0109} & \multirow{2}{*}{0,285} & \multirow{2}{*}{,776 } \\
\hline & Lisans & 4,1274 & ,73563 & & & \\
\hline \multirow{2}{*}{$\begin{array}{l}\text { Engelli Turizmini } \\
\text { Teşvik }\end{array}$} & Ön Lisans & 4,5042 & ,54821 & \multirow{2}{*}{0,0413} & \multirow{2}{*}{1,225} & \multirow{2}{*}{, $221^{*}$} \\
\hline & Lisans & 4,4629 & 66422 & & & \\
\hline \multirow{2}{*}{$\begin{array}{c}\text { Engelli Turizmi } \\
\text { Pazarına Bakış }\end{array}$} & Ön Lisans & 4,2298 & ,58410 & \multirow{2}{*}{0,1670} & \multirow{2}{*}{4,538} & \multirow{2}{*}{, $000^{*}$} \\
\hline & Lisans & 4,0628 & ,72836 & & & \\
\hline \multirow{2}{*}{$\begin{array}{l}\text { Engelli Turizminin } \\
\text { Olumsuzlukları }\end{array}$} & Ön Lisans & 4,3037 & 68729 & \multirow{2}{*}{0,0795} & \multirow{2}{*}{1,988} & \multirow{2}{*}{, $047^{*}$} \\
\hline & Lisans & 4,2242 & ,77553 & & & \\
\hline \multirow{2}{*}{$\begin{array}{l}\text { Engelli Turistlere } \\
\text { Hizmet Etme }\end{array}$} & Ön Lisans & 3,6544 & ,70264 & \multirow{2}{*}{0,1253} & \multirow{2}{*}{3,380} & \multirow{2}{*}{, $001^{*}$} \\
\hline & Lisans & 3,5291 & 69694 & & & \\
\hline \multirow{2}{*}{$\begin{array}{l}\text { Engelli Turistlerin } \\
\text { Farklılıkları }\end{array}$} & Ön Lisans & 3,6044 & 84005 & \multirow{2}{*}{0,1621} & \multirow{2}{*}{3,528} & \multirow{2}{*}{, $000^{*}$} \\
\hline & Lisans & 3,4422 & ,87537 & & & \\
\hline
\end{tabular}

Engelli bireylere ve engelli turizmine bakış boyutlarının eğitim düzeyine göre farklılaşmasına yönelik t-testi sonuçları Tablo 5'de gösterilmektedir. Sonuçlar incelendiğinde, engelli bireylerle ilişki boyutu hariç olmak üzere tüm boyutlarda anlamlı bir farklılığın olduğu görülmektedir $(p<0,05)$. Engelli bireylere bakış boyutunda, ön lisans eğitimi alan turizm öğrencilerinin daha pozitif bir tutum içinde oldukları anlaşılmaktadır (Tablo 5). Diğer yandan engelli turizmini teşvik ve engelli turizmine bakışta da ön lisans öğrencileri daha yüksek katılım göstermiştir. Engelli turizminin olumsuzlarını algılama bakımından, engelli turistlere hizmet etme noktasında da ön lisans öğrencilerinin, lisans öğrencilerine göre daha yüksek katılım gösterdiği anlaşılmaktadır. Ancak farkların çok da büyük olmadığını da belirtmek gerekmektedir. Eğitim düzeyi arttıkça, öğrencilerin engelli turizmi pazarına bakışının değiştiği görülmektedir. Öğrencilerin eğitim gördükleri sınıf ile engelli bireylere ve engelli turizmine bakışlarında bir farklılaşma tespit edilmemiştir ( $p>0,05)$.

Engelli birey tanıyıp tanımama değişkeni bazında faktör analizleri neticesinde ortaya koyulan boyutların tamamına yakınında bir farklılık tespit edilmiştir. Yalnızca engelli turistlerin farklılıkları boyutunda anlamlı bir farklılık tespit edilmemiştir $(p>0,05)$. Diğer tüm boyutlarda engelli birey bir tanıdığı olanların ifadelere daha yüksek katılım gösterdikleri gerek engelli bireylere gerekse engelli turizmi pazarına daha olumlu bir bakış sergiledikleri görülmektedir. Turizm öğrencilerinin staj yapıp yapmamalarına göre engelli turizmine bakışlarında anlamlı bir farklılık tespit edilmemiştir ( $\mathrm{p}>0,05)$. 
Tablo 6. Engelli Bireylere ve Engelli Turizmine Bakış Boyutlarının Engelli Birey Tanıyıp Tanımama Durumuna Göre Farklılaşması**

\begin{tabular}{|c|c|c|c|c|c|c|}
\hline Boyutlar & Değişken** & $\begin{array}{c}\text { Aritmetik } \\
\text { Ortalama }\end{array}$ & $\begin{array}{c}\text { Standart } \\
\text { Sapma }\end{array}$ & $\begin{array}{c}\text { Ortalama } \\
\text { Farki }\end{array}$ & t Değeri & Anlamlılık \\
\hline \multirow{2}{*}{$\begin{array}{l}\text { Engelli Bireylere } \\
\text { Pozitif Bakış }\end{array}$} & Evet & 4,6229 &, 53762 & \multirow{2}{*}{0,1656} & \multirow{2}{*}{5,624} & \multirow{2}{*}{, $000^{*}$} \\
\hline & Hayır & 4,4572 &, 71456 & & & \\
\hline \multirow{2}{*}{ Engelli Bireylerle İlişki } & Evet & 4,2029 & ,67226 & \multirow{2}{*}{0,2241} & \multirow{2}{*}{6,418} & \multirow{2}{*}{, $000^{*}$} \\
\hline & Hayır & 3,9787 & ,79570 & & & \\
\hline \multirow{2}{*}{$\begin{array}{l}\text { Engelli Turizmini } \\
\text { Teşvik }\end{array}$} & Evet & 4,5195 & ,58073 & \multirow{2}{*}{0,1367} & \multirow{2}{*}{4,429} & \multirow{2}{*}{, $000^{*}$} \\
\hline & Hayır & 4,3828 & ,72398 & & & \\
\hline \multirow{2}{*}{$\begin{array}{l}\text { Engelli Turizmi } \\
\text { Pazarına Bakış }\end{array}$} & Evet & 4,1551 & 65498 & \multirow{2}{*}{0,1454} & \multirow{2}{*}{4,293} & \multirow{2}{*}{, $000^{*}$} \\
\hline & Hayır & 4,0097 & ,76718 & & & \\
\hline \multirow{2}{*}{$\begin{array}{l}\text { Engelli Turizminin } \\
\text { Olumsuzlukları }\end{array}$} & Evet & 4,2955 & ,72731 & \multirow{2}{*}{0,1416} & \multirow{2}{*}{3,874} & \multirow{2}{*}{, $000^{*}$} \\
\hline & Hayır & 4,1538 & ,79503 & & & \\
\hline \multirow{2}{*}{$\begin{array}{l}\text { Engelli Turistlere } \\
\text { Hizmet Etme }\end{array}$} & Evet & 3,5871 & 69337 & \multirow{2}{*}{0,0783} & \multirow{2}{*}{2,290} & \multirow{2}{*}{, $022^{*}$} \\
\hline & Hayır & 3,5087 & 72194 & & & \\
\hline \multirow{2}{*}{$\begin{array}{l}\text { Engelli Turistlerin } \\
\text { Farklılıkları }\end{array}$} & Evet & 3,5067 & ,87036 & \multirow{2}{*}{0,0630} & \multirow{2}{*}{1,491} & \multirow{2}{*}{,136 } \\
\hline & Hayır & 3,4436 & ,86929 & & & \\
\hline
\end{tabular}

${ }^{*} p<0,05$ düzeyinde anlamlidir.

**Engelli bir tanıdığınız var mı?

Tablo 7. Engelli Bireylere ve Engelli Turizmine Bakış Boyutlarının Engelli Bireylere Hizmet Edip Etmeme Durumuna Göre Farklılaşması**

\begin{tabular}{|c|c|c|c|c|c|c|}
\hline Boyutlar & Değişken** & $\begin{array}{c}\text { Aritmetik } \\
\text { Ortalama }\end{array}$ & $\begin{array}{c}\text { Standart } \\
\text { Sapma }\end{array}$ & $\begin{array}{c}\text { Ortalama } \\
\text { Farkı }\end{array}$ & t Değeri & Anlamlılık \\
\hline \multirow{2}{*}{$\begin{array}{l}\text { Engelli Bireylere } \\
\text { Pozitif Bakış }\end{array}$} & Evet & 4,4884 & ,79459 & \multirow{2}{*}{0,1031} & \multirow{2}{*}{3,208} & \multirow{2}{*}{, $001^{*}$} \\
\hline & Hayır & 4,5917 &, 52857 & & & \\
\hline \multirow{2}{*}{ Engelli Bireylerle İlişki } & Evet & 4,1455 & 84247 & \multirow{2}{*}{0,0275} & \multirow{2}{*}{0,719} & \multirow{2}{*}{,472 } \\
\hline & Hayır & 4,1179 & ,67976 & & & \\
\hline \multirow{2}{*}{$\begin{array}{l}\text { Engelli Turizmini } \\
\text { Teşvik }\end{array}$} & Evet & 4,4133 & ,76758 & \multirow{2}{*}{0,0800} & \multirow{2}{*}{2,376} & \multirow{2}{*}{, $018^{*}$} \\
\hline & Hayır & 4,4933 &, 58385 & & & \\
\hline \multirow{2}{*}{$\begin{array}{l}\text { Engelli Turizmi } \\
\text { Pazarına Bakış }\end{array}$} & Evet & 4,0375 & 84917 & \multirow{2}{*}{0,0915} & \multirow{2}{*}{2,478} & \multirow{2}{*}{, $013^{*}$} \\
\hline & Hayır & 4,1291 & 63774 & & & \\
\hline \multirow{2}{*}{$\begin{array}{l}\text { Engelli Turizminin } \\
\text { Olumsuzlukları }\end{array}$} & Evet & 4,2140 &, 85787 & \multirow{2}{*}{0,0437} & \multirow{2}{*}{1,097} & \multirow{2}{*}{,273 } \\
\hline & Hayır & 4,2577 & ,71431 & & & \\
\hline \multirow{2}{*}{$\begin{array}{l}\text { Engelli Turistlere } \\
\text { Hizmet Etme }\end{array}$} & Evet & 3,5947 & 78405 & \multirow{2}{*}{0,0447} & \multirow{2}{*}{1,200} & \multirow{2}{*}{,230 } \\
\hline & Hayır & 3,5500 & 67514 & & & \\
\hline \multirow{2}{*}{$\begin{array}{l}\text { Engelli Turistlerin } \\
\text { Farkll1ıkları }\end{array}$} & Evet & 3,4410 & ,95390 & \multirow{2}{*}{0,0595} & \multirow{2}{*}{1,294} & \multirow{2}{*}{ 196 } \\
\hline & Hayır & 3,5006 & ,84031 & & & \\
\hline
\end{tabular}

${ }^{*} p<0,05$ düzeyinde anlamlıdır.

** Daha önce engelli bir turiste hizmet ettiniz mi?

Engelli bireylere daha önce hizmet edip etmeme değişkenine göre boyutlarda bir farklılık olup olmadığına ilişkin yapılan t-testi sonuçları Tablo 7'de aktarılmıştır. Engelli bireylere hizmet etmeyenlerin engelli bireylere karşı daha pozitif bir bakış geliştirdikleri görülmektedir (Tablo 7). 
Diğer yandan benzer şekilde engelli turizmi pazarını teşvik boyutunda da engellilere hizmet etmeyen turizm öğrencilerinin daha olumlu oldukları söylenebilir. Aynı şekilde engelli turizmi pazarına bakış açıları da daha iyimserdir.

\section{DEĞERLENDİRME ve SONUÇ}

Elde edilen bulgular kısmen önceki çalışmaların bulgularıyla eşleşmektedir. Turistler ve turizm çalışanlarında tespit edildiği gibi turizm öğrencilerinin de engelli bireyler ile temas kurarken tedirgin oldukları bu ifadeye örnek olarak gösterilebilir. Turizm öğrencilerinin engelli bireyler ile temas kurarken tedirginlik yaşamalarının birden çok sebebi olabilir. Engelli bireylerin sosyal devlet yetersizlikleri sebebiyle topluma istedikleri seviyede entegre olamayısları buna bağlı olarak toplumdan kopmak zorunda kalmaları ister istemez engelli bireyler üzerinde bir gizem yaratabilmektedir. Bu gizem öğrencilerin "acaba engelli birey ile temasım esnasında yanlış bir şey söyler miyim, yanlış bir şey yapar mıyım, engelli kişiyi rahatsız edip utandırır mıyım?" soruları sebebiyle engellilerden çekinmelerine yol açabilir. Bu unsurun ileriki araştırmalar ile netleştirilmesi Turizm endüstrisi açısından fayda sağlayacağı aşikârdır.

Engelli bireylerin sosyal olarak toplumun bir parçası olarak çalışmaya, üretmeye, gezmeye ve eğlenmeye katılmaları engelli bireyler üzerindeki gizemi ortadan kaldıracak ve engelli birey ile teması günlük hale getirecektir. Bu alanda sorumluluk yine devletin üstüne düşmektedir. Lise, üniversite ve benzeri alanlarda engelli bireylerin eğitimi, istihdamı sağlanmalı ve bir nevi sosyal kaynaştırma eğitiminin bu kez sağlıklı bireylere verilmesi ile hissedilen çekingenliğin yok edileceği düşünülmektedir. Bulgulardan da okunabileceği gibi turizm öğrencilerinin engelli bireylere yardım etmeye ve engelli bireylerle çalışmaya istekli oluşları; engelli bireyler hakkında negatif bir düşünceyi barındırmadıklarını ortaya koymakta, sadece iletişim aşamasında buzların erimesinin beklendiğini belirtmektedir.

Teknolojik gelişmelerin ve ulaşım imkânlarının çoğalmasıyla engelli bireylerin her geçen gün turizm endüstrisinde daha fazla misafir olarak yer alacağ 1 beklenmektedir. Ancak turizm araştırmacıları ve eğitimcileri olarak engelli bireyleri sadece misafir olarak görmekten ziyade ev sahibi olacakları şekilde yetiştirmek üzerimize düşen görevler arasındadır. Bu bağlamda turizm eğitimi veren kurumların engelli bireyler için özel kontenjanlar ayırmaları, lisans ve lisansüstü eğitimlerde engelli bireylere pozitif ayrımclık tanımaları turizm endüstrisinin geleceği açısından önem arz etmektedir. Özellikle lisans eğitimi seviyesindeki müfredatlara Engelli Turizmi dersinin koyulması ve bu kapsamda engel türleri, engelli bireylerin ihtiyaçları, iletişim kurma şekilleri ve mümkün durumlarda işaret dili ve Braille alfabesinin öğretilmesi turizm endüstrisinde ihtiyaç duyduğumuz gereksinimler arasındadır.

Engelli Turizmi alternatif bir turizm türü olarak kabul edilmemelidir. Turizm endüstrisi içerisinde engelli bireylerin seyahatlerini sorunsuz şekilde tamamlayabilmelerine olanak tanımak turizm endüstrisinin kendi görevidir. Engelli turizmi, engelli bireylerin turizme katılmalarını sağlamaktan ziyade engelli bireylerin engellerinin ortadan kaldırılarak endüstri içerisinde sıradan bir turist gibi zaman geçirebilmelerine olanak tanımak şeklinde tanımlanmalıdır.

\section{KAYNAKÇA}

Akın, H. (2001). Ortaçă̆ Avrupası'nda Cadılar ve Cadı Avı. Dost Kitabevi, Ankara.

Altunışık, R., Coşkun, R., Bayraktaroğlu, S. ve Yıldırım, E. (2007). Sosyal Bilimlerde Araştırma Yöntemleri, Sakarya Yayıncilık, Sakarya. 
Arıkan, Ç. (2002). Sosyal Model Çerçevesinde Engelliliğe Yaklaşım. Ufkun Ötesi Bilim Dergisi, 2(1):12-21.

Baykoç-Dönmez, N., Avcı N. ve N. Aslan (1998). Engelli ve Engelsiz Çocuğa Sahip Anne Babalarin Engellilere ve Entegrasyona İlişkin Düşünceleri. Destek Dergisi, 1(1): $25-33$.

Eryılmaz, B. (2010). Turizmde Engelli Pazarının Değerlendirilmesi ve Bodrum Örneği. Yayınlanmamış Yüksek Lisans Tezi, Sakarya Üniversitesi, Sosyal Bilimler Enstitüsü.

Harari, Y. N. (2015). Sapiens: A Brief History of Humankind. Harper: New York.

https://istatistik.yok.gov.tr/ Erişim Tarihi: 19.10.2019.

Kalaycı, Ş. (2010). Faktör Analizi. İçinde SPSS Uygulamalı Çok Değişkenli İstatistik Teknikleri (Ed. Şeref Kalaycı). Asil Yayın-Dağıtım, Ankara.

Kayış, A. (2010). Güvenilirlik Analizi, içinde SPSS Uygulamalı Çok Değişkenli İstatistik Teknikleri (Ed. Şeref Kalaycı). Asil Yayın-Dağıtım, Ankara.

Kitchin, R (1998). Out of Place', Knowing One's Place': Space, Power and The Exclusion of Disabled People. Disability \& Society, 13(3): 343-356.

Koca, C. (2010). Engelsiz Şehir Planlaması Bilgilendirme Raporu. Dünya Engelliler Vakfı, İstanbul

Okur, N. ve F.E. Erdoğan (2010). Sosyal Haklar ve Özürlüler: Özürlülük Modelleri Bağlamında Tarihsel Bir Değerlendirme. Sosyal Haklar Ulusal Sempozyumu 4-5-6 Kasım, Denizli

Özbaba, N. (2000). Okul Öncesi Eğitimcilerin ve Ailelerinin Özel Eğitime Muhtaç Çocuklar ile Normal Çocukların Entegrasyonuna (kaynaştırılmasına) Karşı Tutumları. Yayınlanmamış Yüksek Lisans Tezi, Marmara Üniversitesi, Eğitim Bilimleri Enstitüsü, İstanbul.

Sherry, M. (2004), Overlaps and Contradictions Between Queer Theory and Disability Studies. Disability \& Society, 19(7): 769-785.

Türkiye İstatistik Kurumu, (2018), Nüfus, Konut ve Demografi Verileri

WHO, W. (2011). World Report on Disability. Geneva: WHO.

World Health Organisation (2011) World Report on Disability, Malta

Yenişehirlioğlu E. ve Türkay O. (2013). Engelli Turistlerin Konaklama İşletmelerinde Kabul Görme Düzeyine Yönelik Algılama ve Sorunlar: Karşılaştırmalı Nitel Bir Araştırma - Akademik Turizm ve Yönetim Araştırmaları Dergisi - 1 - 46. 